\title{
THIRD MISSION ACTIVITIES AT THE UNIVERSITY OF MISKOLC
}

\author{
Zita Horváth \\ rector, University of Miskolc \\ 3515 Miskolc, Miskolc-Egyetemváros, e-mail: rektor@uni-miskolc.hu
}

\begin{abstract}
In addition to their teaching and research activities, higher education institutions play an important role in the social development of countries. Their indirect economic impact is unquestionable. The socalled "third mission" summarizes the activities and impacts of higher education institutions on their environment. Beyond the obvious range of training and research services this impact of the higher education institutions is particularly strong, but typically works through indirect and soft means and therefore it is difficult to quantify. The Hungarian network of institutions is potentially suitable for fulfilling its third mission role. Local training, research, economic and regional development connections are given even in the case of institutions with a narrower profile. Community spaces, service (sports, cultural, library, and public collection) infrastructures are available to the local intelligentsia, the institutions act as living knowledge bases, but they often serve as regional centers for cultural and sports activities as well. In my study, I write about the third mission activity of the University of Miskolc.
\end{abstract}

Keywords: third mission, higher education, social development

\section{Introduction}

"The third mission is to utilize the knowledge created in higher education. It also includes all activities related to the economic and social exploitation of the institutional potential of higher education outside the academic environment. The economic dimensions of the third mission of higher education can be diverse: patent activity, the emergence and growth of spin-off companies, cooperation with already wellestablished companies of different sizes, and the flow of human resources between the business and higher education sectors are all part of these dimensions. ... Addressing the challenges of the 21st century, such as the climate change, environmental and water issues, the aging of societies, the health challenges related to migration, poverty, and hunger, i.e. issues of sustainable development, all require the cooperation and collaboration of science and technology. Thus, the education (first mission) and research (second mission) are also important tasks of the higher education." (Inzelt, 2018)

The "Fokozatváltás" medium-term higher education strategy gives a detailed account of the concept and interpretation of the third mission. "In addition to their teaching and research activities, higher education institutions play an important role in the social development of countries. Their indirect economic impact is unquestionable. The so-called "third mission" summarizes the activities and impacts of higher education institutions on their environment. Beyond the obvious range of training and research services this impact of the higher education institutions is particularly strong, but typically works through indirect and soft means and therefore it is difficult to quantify. The Hungarian network of institutions is potentially suitable for fulfilling its third mission role. ... Local training, research, economic and regional development connections are given even in the case of institutions with a narrower profile. Community spaces, service (sports, cultural, library, and public collection) 
infrastructures are available to the local intelligentsia, the institutions act as living knowledge bases, but they often serve as regional centers for cultural and sports activities as well." The third mission is closely related to social innovation. "From a higher education perspective, social innovation is a series of innovative approaches that, in a broader sense, aim to help society adapt to the challenges of today. Important elements of social innovation include for example innovative measures to address employment problems or initiatives that address the social impacts of rapid technological development. A common element of the manifestations of social innovation is that they are always based on very wellgrounded local knowledge. The objective: to broaden science promotion, dissemination, attitudeforming services and to increase the access to higher education knowledge bases ... The public collection network (libraries, archives, collections) and databases of higher education institutions represent a knowledge base in Hungary that is the widest in terms of geographical coverage and has the wealthiest content. Due to this characteristic, the measures and proposals launched at universities and colleges to solve contemporary problems largely shape the attitudes of the younger generations; students leaving higher education will not only be valuable employees, but educated, broad-minded, environmentally conscious, and intelligent members of the society. ... Actions: Active support and extension of Researchers' Night [Kutatók Éjszakája], Science Festival [Tudomány Ünnepe], and The University of All Knowledge [Mindentudás Egyeteme] science promotion programs." (Fokozatváltás a felsőoktatásban, 2016)

In summary, the third mission activity covers the following areas:

- Strengthening the institutional impact on local economic development

- Increasing the activity of the institution in addressing societal challenges and disseminating social innovation

- Broadening science promotion, knowledge dissemination and attitude-forming services, and increasing free access to higher education knowledge bases

- Creating up-to-date information content and provide wide access to it

- Strengthening the service functions of higher education towards both students and the local society: the development of a student service model, strengthening the service function towards the local society

In addition to its classical educational and research tasks, the University of Miskolc has been playing an active role in the field of the third mission for many years. Our medium-term Institutional Development Plan until 2024 also names it as a strategic area. In the followings I summerize our ongoing and planned third mission activities.

\section{Strengthening the impact of the institution on local economic development}

The University of Miskolc has now been placed on the world map, primarily with its unique (hydrogeologist, oil engineer, material technologist, foundry) programs, but there is also a strong demand in the field of doctoral training. The institution consciously worked toward transforming its $R \& D$ portfolio in a way that it strengthened professional profiles based on the needs of the economy and meet the immediate needs of companies. Not only did we purchase new equipment but we also employ fulltime researchers. These efforts were completed in 2018 and 2019 under the Higher Education Institutional Excellence Program established by the Ministry of Higher Education. The research areas of the faculties of the University correspond to the $\mathbf{S 3}$ (smart specialization) directions defined for Borsod-AbaújZemplén county. 
In line with the university's third mission, Social scientific research complements and links research and development activities to social development. The recent establishment of Center of Excellence network at the University of Miskolc. The Center is a hub of professional scientific workshops that meet the research challenges of the 21 st century. Research topics as well as focus areas that are of key importance for competitiveness have been identified. These areas are: Industry 4.0 Materials Science and Robotics, Industry 4.0 Logistics, and Water Management and Cleantech-Greentech Equipment Development.

Previously, significant changes took place in the broader and narrower social, economic, regulatory and management environments of the institution. Although these changes were not always favorable for the University, they still outlined the framework of a new development path. For example, the university has unique engineering programs and corporate base, which enabled the establishment of the first new industrial department after 1945, the Robert BOSCH Department of Mechatronics, followed by the establishment of two MOL Departments. The presence of the University of Miskolc was - and hopefully will always be - an important factor in the decision of the large companies coming to Miskolc. Companies such as Takata (renamed Joyson) or Lufthansa chose Miskolc because of the presence of the University. (Unfortunately, due to the COVID-19 pandemic, the latter did build its plant in Miskolc.) It is our university that trains specialists and develops a strategy for the possible reopening of mines. The University of Miskolc is an institution that is key to the renewal of the steel industry (e.g. foundry programs) and it is also among the few universities the internationally known network of German research institutes, the Fraunhofer Institut is in contact with.

With thoughtful processes of institutional development, the university has created a network of research institutes that opened up new organizational and operational dimensions for companies. As part of this process, we established the Applied Earth Sciences Research Institute (AFKI), the Center for Advanced Materials and Intelligent Technologies - Higher Education and Industrial Cooperation (FIEK), the Electronics and Informatics Research Institute (EIKI) and the modern materials testing 3D laboratory complex which is outstanding in Hungary. These new facilities can efficiently serve industrial needs with their capacities. A new EMC (Electromagnetic Compatibility) laboratory is also being developed, which could also be a host point for business-initiated research and measurements. The proximity of research bases, and the labor supply provided by graduating university students have so far attracted 33 innovative businesses to the university campus. To facilitate corporate relocation processes, the university has begun developing strategic and feasibility plans for a "Science Park" (Science and Innovation Park), that will be one of the eleven parks to be established in Hungary.

The scientific community of SIP embodies an innovation and technology platform in the following fields of science, on which it intends to build an open problem-solving activity and a demand-oriented business model. Each of the three focus areas is closely related and fits into the concept of Industry 4.0:

- Sustainable Natural Resource Management

- Product Identification and Packaging Technology - Logistics 4.0

- Advanced Materials and Technologies

The goal of our institution is to become an internationally recognized research center in well-defined strategic focus areas, to operate high-quality competence centers for the industry and the institutions that, by offering state-of-the-art solutions, are able to respond quickly to the challenges of the economic environment.

Building on our Institutional Development Plan we came up with the "Green and Smart Campus" project for the development of the University's training and infrastructure, in which we established the following competence centers: 
- Central European Integration Research and Competence Center

- Center for Social Innovation Research and Competence

- Climate Policy and Climate Adaptation Research and Competence Center

- Space Material and Technology Research and Competence Center

- Research Group on the History of Innovation, History of Science and History of Technology

- Public Services and Performance Management Research and Competence Center

- Energy Efficient Industrial Investment Competence Center

The institution's role in research is also strengthened by the fact that it has outstanding partners at the forefront of research-oriented developments: NASA, CERN, the already mentioned Fraunhofer Logistics Institutes, Bosch, AUDI, NEMAK, and other well-known organizations. The largest growth-oriented Hungarian companies, such as MOL or the Chinese-owned BorsodChem - Wanhua, also continuously cooperate with us. It is hard to list all the SMEs and large companies partnering with the university. In this area, we do not really need to extend our network, but to intensify the relations. We have concluded a cooperation agreement with the Borsod-Abaúj-Zemplén County Chamber of Commerce and Industry (BOKIK). The BOKIK, which brings together SMEs and multinational companies situated in the county, forms a bridge between the university and the economic actors. For them, we have prepared our competence map (competence sheets) related to R \& D \& I, with the aim of serving as a kind of "menu" for what we can do for the economic actors. We are planning the same in the field of adult education.

It is worth noting that the University of Miskolc has a $5208 \mathbf{~ m} 2$ laboratory- workshop capacity to accommodate the educational research machinery and equipment park, which is supplemented by $\mathbf{2 9 5 4}$ $\mathbf{m}^{2}$ of office and other space. The institution also participates as a key player in the work of clusters organized in the region: it is a member in 8 clusters, which bring together 122 companies. Of these, the Northern Hungarian Automotive Cluster (NOHAC), the Hungarian Space Industry Cluster and the Northern Hungarian IT Cluster are the most significant accredited clusters.

We want to support and promote company-oriented research and development and technology transfer activities by improving the innovation ecosystem at the university and by creating a base that provides complex services. By doing so the connection to economic areas shall contribute to the development of the supplier capacities of the region, and the creation of accessible RDI and business services portfolio. The Technology and Knowledge Transfer Directorate established for the utilization of the accumulated knowledge assets offers the RDI related research capacities to the actors of the economy by collecting it in a competence map. In addition to our research activities, we also support economic life with dual training, the cooperative doctoral program and the curriculum development carried out together with the companies.

By organizing dual workshops, we want to expand the number of our partners in both undergraduate and graduate programs, thus contributing to the increase of the number of dual students.

In 2018 the University of Miskolc won a HUF 900 million grant for research in the areas of Optimizing Natural Resources and Creative Region: Social and Cultural Innovations in the Service of Regional Economic Development and Progress in the framework of the Higher Education Institutional Excellence Program launched by the Ministry of Human Resources. In 2019, within the framework of the Thematic Excellence Program announced by the National Office for Research, Development and Innovation, the University received HUF $\mathbf{4 0 0}$ million in support for research in More efficient exploitation and utilization of underground natural resources. These two programs show the strength of the University. Both programs include our three science/engineering faculties (MFK, MAK, GÉIK), and the Creative Region project brings together the non-technical faculties (ÁJK, GTK, ETK, BTK, 
BBZK) in an elaborate social innovation program that can be a flagship project not only for our university but for the higher education in Hungary as a whole.

\section{Increase the activity of the institution in addressing societal challenges and disseminating social innovation}

The University of Miskolc, as the leading higher education institution in North-Eastern Hungary, operates as an intellectual center that treats the service of the people living in the region and its role in solving the economic and social challenges of the region as a priority during its research, training and project activities. The University does everything in its power to keep the young, skilled workforce here, increase the attractiveness of the region, meet the needs of the local labor market, train professionals for all employers operating in the fields of public education, economy, administration, or health care.

In addition to training, the institution also performs significant third mission tasks by focusing on certain research areas, by applying research results and by giving practical assistance and support. The generators and implementers of these activities are mainly the faculties operating in the field of social science: the Faculty of Arts, the Faculty of Law, the Faculty of Economics and the Faculty of Health Sciences. The faculties have undertaken/ will undertake tasks, research and support in this field both individually and jointly.

The most significant joint activity of the four faculties was launched in 2018 in the framework of the Higher Education Institutional Excellence Program under the title Creative Region: Social and Cultural Innovations in the Service of Regional Economic Development and Progress. Within the framework of the project, 27 settlements of the Abaúj micro-region (one of the most disadvantaged areas of the country and the European Union) is researched, their resources, economic, social innovations, cultural values and community life is mapped through empirical and secondary research. The aim of the project is to create a social innovation model based on the local knowledge, resources, values and characteristics, which contributes to the revitalization of the region's economy, tourism development, improvement of the quality of life of the inhabitants and increase the region's attractiveness. The model shall also be adaptable in other areas with similar characteristics.

The $4^{\text {th }}$ sub-project of the EFOP 3.4.4. Phoenix - Renewable University [Fönix - Megújuló Egyetem] project dealt specifically with the topic of social innovation, but the 3rd sub-project (educational innovation) was also involved in this area of institutional development. The sub-project includes several activities addressing the disadvantaged target groups as well as the actors of economic life in a complex way along the principles of the higher education disadvantage compensation model. The following activities were carried out within the framework of the project:

- Upward mobility programs: popularization of science (25 lectures), Phoenix Academy,

- Women in higher education - events: Girls' Day events (4 events),

- Competence measurements, mentoring programs, development of practical places in disadvantaged regions,

- Public participation: Phoenix Academy,

- Internship Program: Together with the Greek Catholic Roma College.

The EFOP-3.1.2.-2016-00001, Methodological renewal of public education in order to reduce school drop-out project involved the public education institutions of Borsod-Abaúj-Zemplén county. The project supported methodological culture of teachers and intended to help disadvantaged students. By developing and disseminating pedagogical methods suitable for preventing drop-out in the institutions the University of Miskolc provided teacher training programs that support the 
methodological culture and attitude change of teachers. The University of Miskolc offered trainings for 2367 teachers in 98 educational institutions of the county.

Relying on its own resources, the University of Miskolc contacted county public education institutions providing them a training portfolio that responds to local These trainings provided theoretical and practical support for the more effective education of students who are living in difficult circumstances, are under-motivated and have learning difficulties. The institution provided the following trainings to achieve the objectives of the project:

- Complex Instruction Program (KIP) (30 contact hours),

- Burnout prevention and stress management with reflective techniques (30 contact hours),

- Chance - Motivation - Catching up (30 contact hours),

- Roma culture (90 contact hours),

- Együtthaladó - Learning Togehter (30 contact hours),

- Lego-robot program (30 contact hours).

The Teach for Hungary! [Tanítsunk Magyarországért!] offers direct help for disadvantaged pupils through mentoring. Under the project, full-time university students mentor disadvantaged students in schools in the small towns of the county with the aim of helping them in their studies, supporting students in completing school, achieving successful admission to secondary school, transferring them to various cultural programs, motivating them to study. A student mentors 3-4 students in $7^{\text {th }}$ or $8^{\text {th }}$ grade. Currently, the mentoring program covers the following settlements: Arnót, Aszaló, Bükkaranyos, Boldva, Hejőkeresztúr, Kisgyőr, Megyaszó, Mezőzombor, Onga, Ónod, Prügy, Sajóbábony, Szendrő, Szendrőlád, and Taktakenéz.

In addition to the third mission activities carried out within the framework of the projects, the Institute of Applied Social Sciences of the Faculty of Arts regularly carries out third mission activities.

- Programs run in the social media platforms: Issues of existence, points of existence, Vital Signs (at the time of the epidemic).

- Every year the institute organizes the regional round of the national competition for high school students with the Wallenberg Association.

- The Week of Social Work is organized every year.

- Undergraduate students of the social work program volunteer for local social and child welfare institutions.

- The institute collaborates with several foundations in which students do volunteer work.

- The institute provides support to the Gyula Fényi Jesuit Grammar School in preparing their students for 50 hours of community work.

In summary, the faculties involved in the implementation of the third mission objectives of the University of Miskolc carry out extremely versatile tasks. In accordance with their profile, they do extensive social, cultural and educational research, offer trainings, participate in application development, provide health screening, mentoring and legal services. The need for synergy between the diverse activities, the practical tasks and the research results required the establishment and operation of a Social Innovation Research and Competence Center, which coordinates all the activities related to the field.

We have set up a Community Service Office at the university to host high school students for their required 50 hours of community service. In addition, we help our own students to get involved in voluntary, helpful activities. 


\section{Science promotion, knowledge dissemination, attitude-forming services and increasing free access to higher education knowledge and Creating up-to-date information content and providing wide access to them}

Two of our projects have achieved significant results in these areas. In the Phoenix project, we gave science-promoting lectures (25 lectures) and organized the Phoenix Academy. In the Castle of Knowledge [Tudás Vár] project, the MAKadémia (materials science playhouse), video blog posts, thematic days, MeMat software, scientific and educational lectures, summer camps (12 camps), the 3D software presenting our Training Mine and publication of the book "MEnők. Nők a tudományban" are worth to mention. Of these, the METMI engineering vlog is one of the results, that are highly accessible for the general public. The name originates from a word-game. It created by using the abbreviation of the University of Miskolc (ME), the STEM subjects (MTMI) and the English expression Meet me. The video-blog series serve to promote our STEM related academic programs. The short episodes present an interesting aspect of the STEM related subjects with interesting and exciting visual effects. The films are suitable for attracting the attention of primary and secondary school students, and for promoting STEM related programs, but can also be used in the training of university students.

The Academy of Natural Resources (TEA) should also be mentioned. The aim of the TEA series of events is to make the lectures of renowned Hungarian and international scientists, professors, academics or even world travelers available to all interested parties free of charge. The academy was launched by the Faculty of Earth Science and Engineering for high school students and their teachers, university students and faculty, and all interested professionals. Two lectures were given per semester, on water, the environment, fossil and renewable energies, geothermal energy, the natural environment, the greenhouse effect, climate policy, recycling, minerals and earth sciences. The presentations were recorded and can be viewed on YouTube as part of the project.

Here is an example of the lectures in the TEA series:

- https://www.youtube.com/watch?v=Og4hQMkiNHw

We also consider summer camps for primary and secondary school students in to be a sciencepromoting event.

Center of Adventures: Within the framework of the Castle of Knowledge project, we opened a new facility at the University of Miskolc 10 December, 2018. The Center focuses on skill and ability development, are is based on different topics, presenting the main academic programs of the University. In this way, young people can get to know the educational portfolio of the University of Miskolc by solving challenges, puzzles and riddles. Two escape rooms were created withing the project, and a number of experience-based demonstration tools and interactive games make the Center an exciting and memorable place to visit. The Center of Adventures can be used free of charge by all primary and secondary schools during school trips or classes.

YouTube video on the two escape rooms:

- https://www.youtube.com/watch?v=hv8SmQxRYks

- https://www.youtube.com/watch?v=Q81Us7wOie4

Training Mine: The Training Mine of the University of Miskolc served originally as a bomb shelter. After the world war it lost its purpose was transformed into a training mine between 1959-1962. Nowadays, it is hardly possible to visit an underground mining plant in the country, to see the operation of a mine. Visits to the training mine bring geography and chemistry closer to the students, reveal the exciting world of earth science, show the practical benefits of geodetic measurements, and present the effects of science on our daily lives. The training mine has a direct and indirect effect on motivating 
pupils to enter higher education. As part of the Castle of Knowledge project, the Training Mine has become accessible through a VR application.

The Faculty of Health Sciences together with the Central- Eastern-European Recreational Association organizes and holds science-promotion events.

The Miskolc Regional Committee of the Hungarian Academy of Sciences offers science-promotion lectures on a regular basis. I would like to highlight the science-promoting lectures within the framework of the Academy of the Elderly program, that focus on active aging.

\section{Strengthening the service functions of the higher education for students and the local society}

The uniqueness of the University of Miskolc comes partly from the fact that all its faculties are situated in one campus. Covering nearly 100 acres, the university has all the services to make the university years memorable and comfortable for students, and to provide our faculty members and staff nice and livable environment. Seven dormitories provide accommodation for students, lecturers (2000 beds), buffets, university canteen, complete sports infrastructure (sports hall, gyms, football pitches, running track, heated running corridor, tennis courts, basketball and handball courts, swimming pool), library, doctor's office are available for the students, faculty members and staff. The educational buildings, the student administration center, the career office are all located on site within a few minutes of walk. Parking lots and bicycle storage stands make the campus even more accessible. The Foreign Language Education Center provides free language lessons twice a week for all students, and operates as an exam center available not only for university citizens. Moddle and MEMooc distance learning systems support online education. Wi-Fi is available at the university, although it needs improvement. The university library is also a public library available to anyone.

The pandemic situation brought new challenges to our university. It was a time, when our third mission became extremely important.

- We organized mandatory trainings for healthcare professionals. To date, more than 4,000 professionals finished the training.

- We organized optional free trainings for healthcare professionals. So far, nearly 1,000 people have participated in them. All the trainings are accredited.

- During the pandemic, about 100 students of the University of Miskolc carried out voluntary work in the field of social care. It involved shopping, helping the elderly, and participating in the Red Cross' work in health screening at the Hungarian borders. In the fall, more than 100 students worked on a voluntary basis at the hospitals collecting samples for testing. In addition to the testing, they were also involved in hospital work. Several students have worked in the COVID intensive care unit (e.g. in physiotherapy). One of our psychologists offered consultation to process the work-related experiences and traumas.

- In the first wave of the pandemic, epidemiological information, epidemic, infection and virus-related scientific briefings and spiritual advice were provided in the faculty's website.

- In collaboration with the Red Cross one of our colleagues is involved in a campaign against menstrual poverty. (so far, she has given lectures to about $2007^{\text {th }}$ grade students living in disadvantaged settlements.)

- We provide interactive lectures on bullying and aggression for secondary school students. To this date approximately 4,000 high school students participated in the program.

- In cooperation with the Red Cross we organize blood donation events on a regular basis. 
- Our University participates in the Open University for Crime Prevention program.

- We provide free legal advice as part of the Legal Clinic Program.

- For the second year in a row, our faculties help secondary student to prepare for the school leaving exam by offering courses in health science, history, literature, geography, social studies, mathematics and physics for free of charge.

- Our lecturers are the mentors of the disadvantaged students of the Greek Catholic Roma College.

The list of third mission activities of the University of Miskolc is far from being complete. This short summary of diverse activities show that the University of Miskolc has a significant presence in the region and carries out tasks that go beyond the classical educational and research activities of universities.

\section{References}

[1] Inzelt, A. (2018). A felsőoktatás harmadik missziója. Valóság, 2018, 93-99. (https://www.researchgate.net/profile/Annamaria-

Inzelt/publication/325426516_A_felsooktatas_harmadik_misszioja/links/5b0d7d4b0f7e9b1ed7 007db2/A-felsooktatas-harmadik-misszioja.pdf

[2] Fokozatváltás a felsőoktatásban. Középtávú felsőoktatási szakpolitika. (2016). https://20152019.kormany.hu/download/c/9c/e0000/Fokozatvaltas_Felsooktatasban_HONLAPRA.PDF 